\title{
Numerical investigation of the internal flue gas recirculation system applied to methane powered gas microturbine combustor
}

ARTICLE INFO

Received: 29 June 2021

Revised: 2 August 2021

Accepted: 25 August 2021

Available online: 26 August 2021
The gas microturbines gain significance in various industry sectors. One of their most crucial advantages is the capability of utilizing variety of fuels. At the same time, the emissions regulations become increasingly strict. This is why there is a need to look for a new technological solution to limit the emissions of selected substances, like carbon monoxide $(\mathrm{CO})$ and nitrogen oxides $\left(N \mathrm{O}_{x}\right)$. The internal recirculation of the flue gases is well known to limit the temperature peak and for the homogenization of the temperature field gradient in different combustion chambers. This paper presents a numerical investigation of a novel internal flue gas recirculation system applied to gas microturbine combustors. The ability to perform an internal exhaust gases recirculation by adding a combustor internal pipe system was verified numerically. This paper exposed the numerical investigation methods and obtained results. The study presents the concept and results performed on three cases of internal exhaust gases recirculation systems applied to a reference combustor. The work permitted to demonstrate numerically that it is possible to perform an autonomous exhaust gases recirculation inside gas microturbine combustor at a maximum global rate of $0.51 \%$, and that the recirculation system has an impact on the combustion processes without specially modifying the combustor work parameters.

Key words: gas microturbine, exhaust gases recirculation, combustion chamber, $C O$ emission, $N O_{x}$ emission

This is an open access article under the CC BY license (http://creativecommons.org/licenses/BY/4.0/)

\section{Introduction}

Gas microturbines are engines used to convert fuel energy into mechanical and/or thermal energy. These devices are used in locations where waste fuel is generated (described by Chitrarth Lav and Raj Kumar Singh [1]), as emergency electricity generators for hospitals, as a power drive for drones and even cars (Jaguar C-X75 or Pininfarina $\mathrm{H} 600)$, etc. In the near future, it is expected that gas microturbines applicability will grow substantially. This expectation is related to the multiple advantages of microturbines. It has a compact design, high power to mass ratio, limited number of rotating parts, low noise pollution level, low vibration level, high potential for the use of various fuel, etc. [1].

Since few decades, more restrictive environmental regulations are being enforced and gas turbine producers are forced to maintain the agreement between efficient and clean combustion. The major pollutants are the nitrogen oxides $\left(\mathrm{NO}_{\mathrm{x}}\right)$ and carbon monoxide $(\mathrm{CO})$. The main engineering objective of this work is to elaborate a new type of combustor solution that could be adopted to energy devices.

The use of the gas microturbine considering emission regulations leads to the development of new types of combustor for gas microturbines. This paper investigates a novel concept of combustor for gas microturbine equipped with an internal exhaust gas recirculation system. The exhaust gas recirculation system is often applied to piston combustion engines and to power industry gas turbines. The recirculation system may be realized by adding a pipe system permitting to transfer a part of the exhaust gases into the inlet of the power device. This solution is often called the External Flue Gas Recirculation (EFGR). Another recirculation system may be based on transferring part of the exhaust gases from the end of the combustion zone, in power device combustor, to the combustion zone. This is called Internal Flue Gas Recirculation (IFGR). The role of recirculating exhaust gases is to reduce the temperature peaks and its gradients, which have a direct impact on the reduction of thermal NOx. In this paper, a gas microturbine combustor equipped with a novel IFGR system is investigated numerically. The current paper describes the numerical investigation of the above-mentioned design solution.

Numerical methods are often used in order to verify and optimize design solutions. The works of Sarlej et al., Chen and Liu, Liu et al., Kim et al. and Huang et al. were oriented on the combustion investigation of the burner and were performed using numerical tools [2]. In the work [3] the influence of the heat supplied into the combustor of the gas microturbine GTM-120 on the aerodynamics of the flow through the combustor was numerically investigated. The work presented a cold flow analysis and the combustion was not simulated in the combustor. The authors underline that the applied RANS k-epsilon model gives accurate results.

The work [4] describes a numerical simulation of the combustion chamber of the gas microturbine GTM-140. The authors used the RANS k-epsilon turbulence model, the non-premixed combustion model and the Discrete Ordinates radiation model. The obtained flow and combustion parameters were compared with the experimental data. It permitted to validate the mathematical models used to perform the simulation.

The work [5] presented a numerical investigation of the influence of the reference area on the velocity profile, temperature field, mixing process and the flame behaviour, in a gas microturbine combustor. The authors used the Shear Stress Transfer turbulence model, the P-1 radiation model and the Eddy Dissipation model for the combustion. The results were compared with the calculation methodology presented by Lefebvre and performed in GateCycle pro- 
gram. The results from the simulation and from the Lefebvre calculation methodology were similar. This work shows that the use of various methods (simulation and calculation methodology) permitted to investigate phenomena without using real devices.

In the work [6] a flow with combustion processes occurring in gas turbine was investigated. The numerical results were compared with experimental results, and many of the performed simulations were accurate. The work presented many combustion models (Eddy dissipation model, Finiterate chemistry model, Flamelet model, Burning velocity model, Extended coherent flame model, Monotone integrated LES, and Linear eddy mixing model). In this work, the Flamelet model appears to be an interesting solution to simulate the combustion processes in gas turbine. This model permits to get an accurate temperature and species field using a detailed chemistry, while having shorter calculation time than other more complex combustion models.

In the work [7] the KJ66 gas microturbine combustor was simulated. In this work, the steady flamelet model with a reduced mechanism of 63 species and 167 reactions (kerosene fuel) was used. In terms of the combustion modelling, the temperature field at the outlet of the combustor was in agreement with the experimental results.

Novelty of the current paper is based on introduction of a totally new concept of recirculating exhaust gases by adding an autonomous pipe system directly inside the combustor. In previous research the recirculation process was realized by the vortex generation but not by adding a pipe system.

This study aims to perform a numerical investigation in order to assess the ability to obtain an autonomous exhaust gases recirculation and analyze its impact on the combustion processes and work parameters of the gas microturbine combustor.

\section{Case study combustor and operating conditions}

A referential combustor was designed to be suitable for microturbine application. It has a nominal power of around $40 \mathrm{~kW}$ and it is fired with methane. The designed combustor calculated work parameters are listed in the table 1, while the characteristic cross sections of the gas microturbine are shown in Fig. 1. The scheme of the referential combustor is presented in Fig. 2.

Table 1 The referential gas microturbine and combustor work parameters

\begin{tabular}{|c|c|c|c|c|c|}
\hline Parameters & $\mathrm{H}$ & 1 & 2 & 3 & 4 \\
\hline $\mathrm{p}^{*}[\mathrm{~Pa}]$ & 101325 & 99298 & 324992 & 311992 & - \\
\hline $\mathrm{p}[\mathrm{Pa}]$ & 101325 & 90918 & 306584 & 301133 & 101325 \\
\hline $\mathrm{T}^{*}[\mathrm{~K}]$ & 288 & 288 & 433 & 1185 & - \\
\hline $\mathrm{T}[\mathrm{K}]$ & 288 & 280 & 426 & 1175 & - \\
\hline $\mathrm{c}[\mathrm{m} / \mathrm{s}]$ & 0 & 120 & 120 & 155 & $\sim 80$ \\
\hline $\mathrm{c}_{\mathrm{s}}=4.874 \cdot 10^{-3} \frac{\mathrm{kg}}{\mathrm{s}} ; \mathrm{m}=0.251 \frac{\mathrm{kg}}{\mathrm{s}}$ & \\
\hline
\end{tabular}

The main objective of this investigation is to check the possibility to design an autonomous IFGR system applied to gas microturbine combustor. The main technical issue is that the exhaust gases are transferred to a combustor region representing higher pressure. The proposed novel combustor design takes this fact into account.

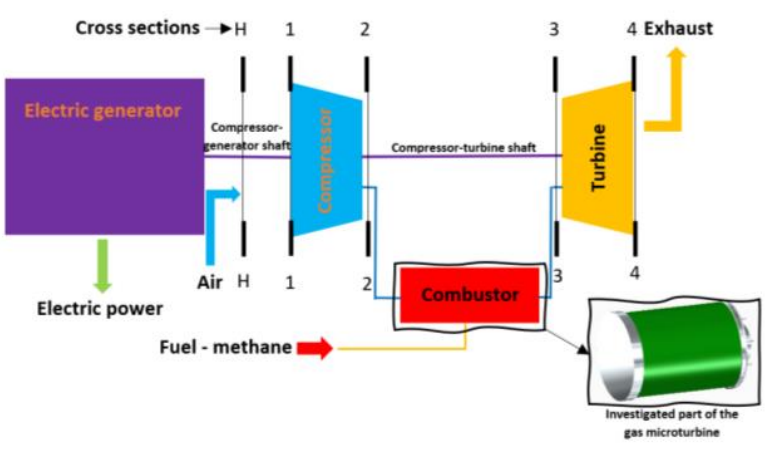

Fig. 1. The cross sections available for the analysed gas microturbine

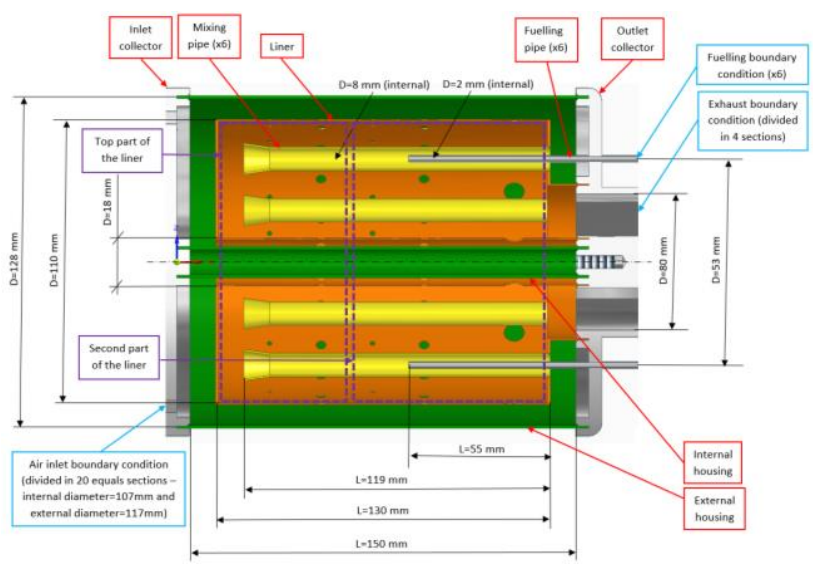

Fig. 2. The scheme of the referential combustor in 3D model

Investigation of the IFGR system applied to the gas microturbine was divided into three major concepts of the modified referential combustor.

The first modified combustor (Case A) is presented in Fig. 3 with this IFGR system concept. Additional IFGR pipes are connected to the existing mixing tubes in the vicinity of their outlets. The idea behind this concept is to redirect part of the exhaust gases into the fresh air-fuel mixture.

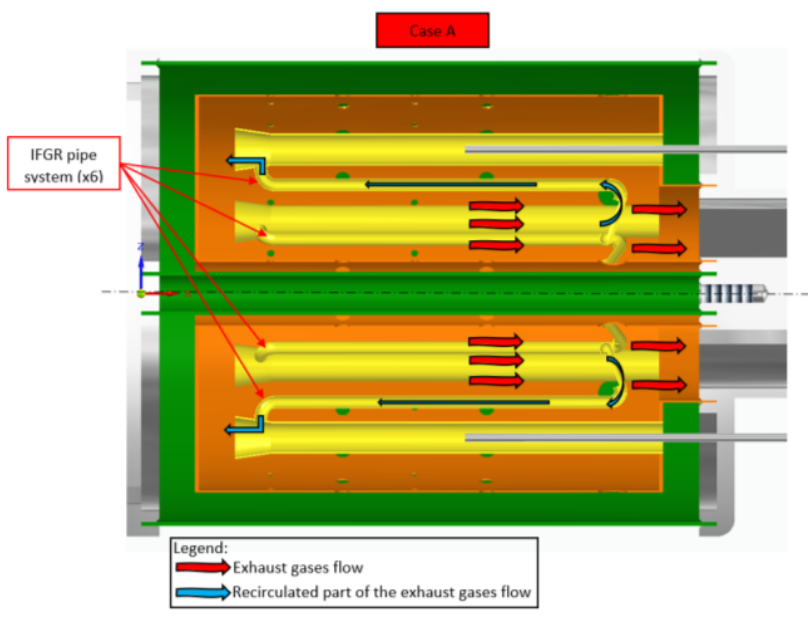

Fig. 3. Modified combustor (Case A) 
The second concept of modified combustor (Case B) is presented in Fig. 4. In this IFGR case, additional pipes are installed outside of the liner which permits to transfer a portion of exhaust gases from the outlet of the combustor into the combustion zone, located at the beginning of the liner. The third combustor concept (Case C) is presented in Fig. 5. This IFRG solution consists of adding a pipe connected to the base of the mixing tube. The internal channel of the mixing pipe is shaped as a venturi tube, which permits to generate sufficient under pressure acting as a driving force able to direct the exhaust gases and mix them with air in the mixing pipe.

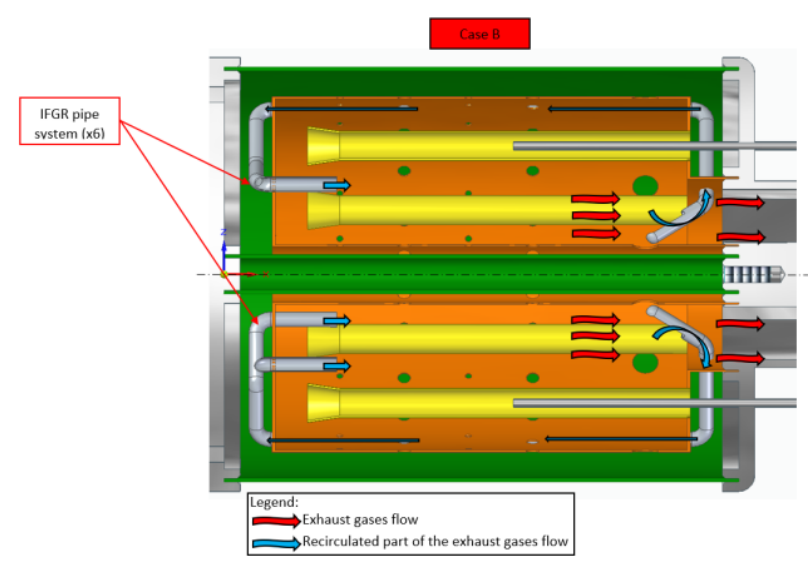

Fig. 4. Modified combustor (Case B)

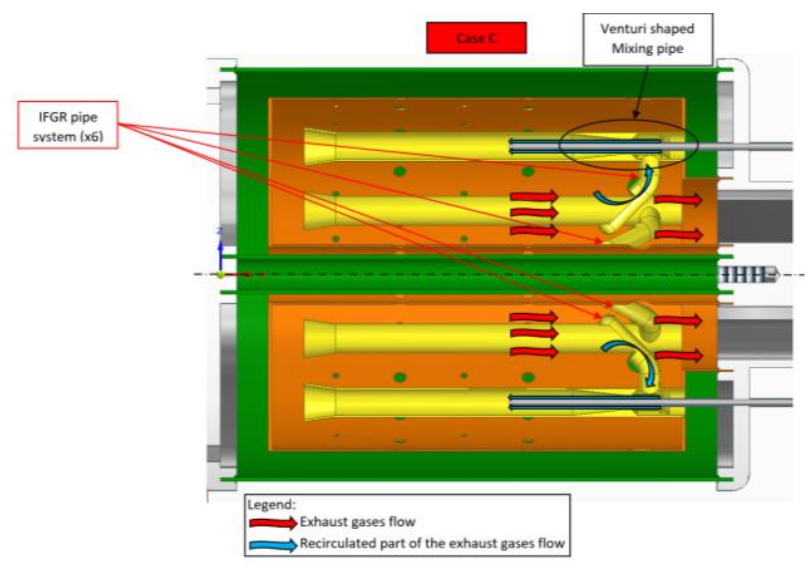

Fig. 5. Modified combustor (Case C)

\section{Numerical methods}

\subsection{Computational domain grid system}

The three-dimensional geometry was created using Solid Edge and Ansys preprocessor [8]. Computational domain is shown in Fig. 6. Mesh is one of the most important factors in the simulation of the combustion chamber. To resolve the major flow properties, the tetrahedral cell system is often created. It was previously proven that this meshing solution is successful in case of gas microturbines combustors [3-7]. This kind of element permits to fill a complex geometry, while keeping correct values of quality parameters (skewness, orthogonality and aspect ratio). Recently, the polyhedral cell mesh was intensively developed and then analyzed. This kind of cells are considered to give relatively good results, similarly to the tetrahedral elements, while obtaining elements with better quality parameters [911]. Finally, the polyhedral mesh with a maximum cell length of $0.8 \mathrm{~mm}$ was selected for this study. The volume mesh was improved by selecting the value of 0.45 for the cell quality limit (desired orthogonal quality). Additionally, boundary layers were generated in order to not exceed the $\mathrm{Y}+$ value of 300 . Table 2 shows the quality parameters of the obtained mesh system.

Table 2. Quality parameters of the meshes

\begin{tabular}{|l|c|c|c|c|}
\hline Case & $\begin{array}{c}\text { Number of } \\
\text { cells } \\
\text { [millions] }\end{array}$ & $\begin{array}{c}\text { Maximum } \\
\text { aspect ratio }\end{array}$ & $\begin{array}{c}\text { Maximum } \\
\text { skewness }\end{array}$ & $\begin{array}{c}\text { Minimum } \\
\text { orthogonal } \\
\text { quality }\end{array}$ \\
\hline Reference & 5.8 & 38.3 & 0.895 & 0.435 \\
\hline Case A & 6.3 & 93.2 & 0.899 & 0.420 \\
\hline Case B & 7.0 & 35.8 & 0.900 & 0.432 \\
\hline Case C & 6.4 & 62.0 & 0.895 & 0.200 \\
\hline
\end{tabular}
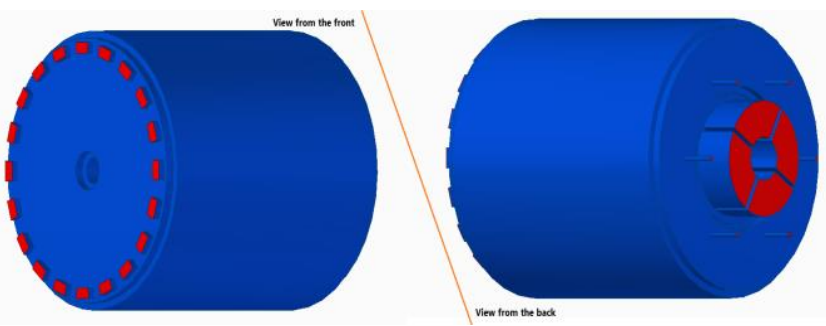

Fig. 6. External view of the computational domain (the external view is similar in all cases)

\subsection{Mathematical model}

The mathematical model used here is based on the commercial CFD code Ansys FLUENT [12]. Simulation of the following processes occurs in the combustor: turbulent flow, gas phase combustion and radiative transport.

Realizable k- $\varepsilon$ model $[13,14]$ was used as a closure of the turbulent Reynolds equations. The realizable k- $\varepsilon$ model is relatively widely used for engineering applications and provides better performance in many industrial turbulent flows than the standard $k-\varepsilon$ model. The enhanced wall treatment was enabled. This model permits to resolve the flow when the value of $\mathrm{Y}+$ is less or equal to 1 , or to apply the enhanced wall function if the value of $\mathrm{Y}+$ is greater than 1. This wall treatment is a good compromise in the case when the phenomena arising at the wall do not have a crucial impact on the general flow properties, like in our case.

In case of combustion in furnace problem, radiation is not only the dominant energy transport mechanism but also one of the most complex problems. A Discrete Ordinates method [4, 14] was used to evaluate the radiative heat transfer. In a typical combustion chamber, $\mathrm{H}_{2} \mathrm{O}$ and $\mathrm{CO}_{2}$ are the main gaseous absorbers and emitters of radiant energy. The total emissivity of gas is calculated by a number of gray gases using polynomial correlations for weighing factors and absorption coefficient according to Weighted Sum of Grey Gases method [14]. Widely employed coefficients for emissivity [15], fitted from the benchmark exponential wide-band model, have been used in this work. The WSGGM represents the entire spectrum with three gray gases having uniform absorption coefficients. The total gas phase absorption coefficient is calculated from the total 
emissivity with the mean path length calculated from the characteristic cell size. The wall emissivity was set to unity, which is a typical recommendation in gas microturbine combustor simulations [16].

The non-premixed steady diffusion flamelet model [17] was used as a general concept for treating the interaction between turbulence and chemistry in flames. The assumption is that turbulent diffusion combustion processes can be described as an ensemble of discrete, steady laminar flames, called flamelets. These flamelets are similar to opposite laminar diffusion flames and can be calculated using detailed chemical mechanism, which means that kinetic effects play an important role here. This formulation also takes into account local turbulence effects via strain rates. Thus, with flamelets, the results are not only dependent on the local mixture of fuel and oxidizer and enthalpy levels, but also on the local turbulence. Based on the flamelet, a look-up pdf table is generated

The flamelets were created on the base of the detailed GRI-MECH 3.0 mechanism [18]. This is a 53 species mechanism with 325 reactions created to model the combustion process of methane. Firstly, the Grimech 3.0 mechanism and thermodynamic files were downloaded from the Berkeley website [18]. These files were introduced into the Fluent software using the non-premixed steady diffusion flamelet model first dialog window. Then, the fuel was modelled as pure methane and the air was simplified to $23 \%$ mass fraction of oxygen $\left(\mathrm{O}_{2}\right)$ and $77 \%$ mass fraction of nitrogen $\left(\mathrm{N}_{2}\right)$ (these parameters were selected in the second dialog window). Finally, based on these files and fuel/oxidizer parameters, the flamelet and the pdf look-up table were generated, according to the Fluent software predefined parameters (in the next dialog windows). The use of the pdf look-up table is an interesting method for combustion modeling, because the physical and chemical proprieties (such as density, temperature and species mass fraction) of the flow are determined based on this table and some parameters, such as local mean mixture fraction and its variance, the scalar dissipation and the mean enthalpy, which are calculated. Once this process is achieved, the turbulent combustion model is ready to perform calculations in the fluent software.

Boundary conditions are discussed below. Inlet: experimental data at the entry are used. Outlet: it is assumed that in case of the exit plane normal to the $\mathrm{x}$-direction, the gradients of all variables except pressure are zero. Values of $\mathrm{x}$ velocity at the exit are initially assumed to be the same as those immediately upstream of the exit plane and subsequently scaled appropriately to satisfy the overall mass conservation. Hence, at the exit plane it may be written as $(\partial \varphi / \partial x)$ exit $=0$. Wall: at the wall, no slip condition is applied and the values of velocity components are set to zero. The flow near the wall is influenced by molecular viscosity rather than by turbulence. The wall function method of [19] uses algebraic formulations to link quantities at the wall to those further away. The boundary conditions were implemented as described in the next Table 3.

The spatial discretization was of the second order [4], with a pressure-velocity coupled method and the pseudotransient approach [20]. The pressure based solver was used.
Table 3. Implemented boundary conditions

\begin{tabular}{|c|c|c|}
\hline $\begin{array}{l}\text { Designa- } \\
\text { tion of the } \\
\text { boundary } \\
\text { condition }\end{array}$ & Type & Parameters \\
\hline Air inlet & $\begin{array}{l}\text { Mass Flow } \\
\text { Inlet }\end{array}$ & $\begin{array}{l}\text { Mass flow }=0.251 \mathrm{~kg} / \mathrm{s} \mid \text { Turbulent } \\
\text { Intensity }=15 \% \mid \text { Turbulent Viscosity } \\
\text { Ratio }=10 \mid \text { Total Temperature = } \\
\text { 433.834 } \mathrm{K} \mid \text { Mean Mixture Fraction =0 } \\
\text { Mixture Fraction Variance }=0\end{array}$ \\
\hline Fuel inlet & $\begin{array}{l}\text { Mass Flow } \\
\text { Inlet }\end{array}$ & $\begin{array}{l}\text { Mass flow }=0.004874 \mathrm{~kg} / \mathrm{s} \mid \text { Turbulent } \\
\text { Intensity }=15 \% \mid \text { Turbulent Viscosity } \\
\text { Ratio }=10 \mid \text { Total Temperature }=300 \mathrm{~K} \mid \\
\text { Mean Mixture Fraction }=1 \mid \text { Mixture } \\
\text { Fraction Variance }=0\end{array}$ \\
\hline Exhaust & $\begin{array}{l}\text { Pressure } \\
\text { Outlet }\end{array}$ & $\begin{array}{l}\text { Static Pressure }=0 \mathrm{~Pa} \mid \text { Turbulent Inten- } \\
\text { sity }=15 \% \mid \text { Turbulent Viscosity Ratio }= \\
10 \mid \text { Backflow Total Temperature }=300 \\
\mathrm{~K} \mid \text { Mean Mixture Fraction }=0 \mid \text { Mixture } \\
\text { Fraction Variance }=0\end{array}$ \\
\hline Wall & Wall & $\begin{array}{l}\text { Stationary Wall | No Slip | No Heat } \\
\text { Exchange | Internal Emissivity = } 1 \text { | } \\
\text { Opaque Wall | Diffuse Fraction of Radia- } \\
\text { tion =1 }\end{array}$ \\
\hline $\begin{array}{l}\text { Operating } \\
\text { conditions }\end{array}$ & - & $\begin{array}{l}\text { Operating pressure }=301133.803 \mathrm{~Pa} \mid \\
\text { Gravity off }\end{array}$ \\
\hline
\end{tabular}

\section{Results and discussion}

The combustors can be characterized using various parameters. In this study, the ability to perform the autonomous exhaust recirculation was analysed. The impact of this IFGR system implementation on the pressure drop was assessed and the influence on combustion processes will be evaluated by the analysis of temperature fields and evolution of $\mathrm{CO}$ and $\mathrm{NO}_{\mathrm{x}}$ emissions.

\subsection{Ability to recirculate exhaust gases}

In this section the numerical simulation results of the three cases are discussed. Numerical simulations prove that it is possible to perform an autonomous exhaust gases recirculation inside gas microturbine combustor at a maximum global rate of $0.51 \%$ and that the recirculation system has an impact on the combustion processes without significantly modifying the combustor work parameters. Figure 7 shows the calculated air mass flows and recirculated exhaust gases across the mixing pipes for different cases.

Based on the performed simulations, the recirculated exhaust gases mass flows in each combustor case were performed. IFGR ratios were calculated following the definitions given by equations 1 and 2 . The parameter IFGR\% refers to the ratio of the recirculated exhaust gases mass flow to the air mass flow passing across the mixing pipe, while the parameter IFGR\%* refers to the ratio of the recirculated exhaust gases mass flow to the exhaust gases mass flow leaving the combustor. The table 4 represents the calculated ratios.

$$
\begin{aligned}
\text { IFGR } \% & =\frac{\text { Recirculated exhaust gases mass flow }[\mathrm{kg} / \mathrm{s}] \cdot 100}{\text { Air mass flow passing across the mixing pipe }[\mathrm{kg} / \mathrm{s}]} \\
\text { IFGR } \%^{*} & =\frac{\text { Recirculated exhaust gases mass flow }[\mathrm{kg} / \mathrm{s}] \cdot 100}{\text { Exhaust gases mass flow leaving the combustor }[\mathrm{kg} / \mathrm{s}]}
\end{aligned}
$$



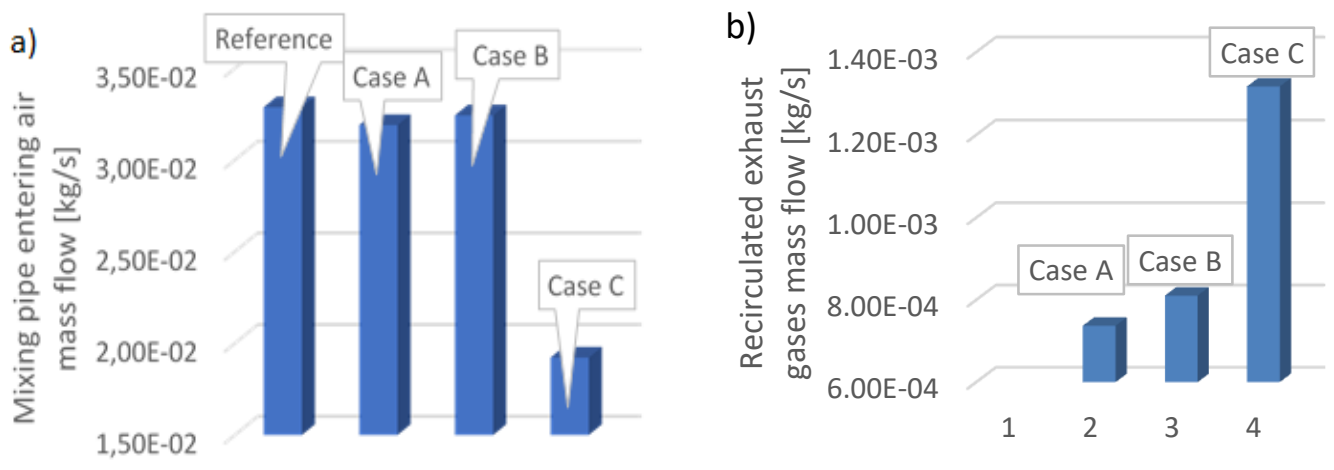

Fig. 7. a) Air mass flow across the mixing pipes, b) Recirculated exhaust gases

Table 4. The IFGR ratio

\begin{tabular}{|l|c|c|}
\hline Case & IFGR $\%$ & IFGR\%* \\
\hline Reference & 0 & 0 \\
\hline Case A & 2.31 & 0.29 \\
\hline Case B & 2.50 & 0.32 \\
\hline Case C & 6.85 & 0.51 \\
\hline
\end{tabular}

The IFGR ratio is the most significant in case $\mathrm{C}$ (Table 4) with the value of $0.51 \%$ for IFGR* and around $6.85 \%$ for IFGR. In cases $\mathrm{A}$ and $\mathrm{B}$ the IFGR ratios are comparable having values of around $0.29 \%$ and $0.32 \%$ respectively and $2.31 \%$ and $2.5 \%$ for IFGR*. The difference between each case is due to design differences. In the cases A and B, the recirculation of the exhaust gases is accomplished by creating a pressure difference between the collection and injection locations. The difference between the total pressure (in the location where the exhaust gases are collected) and static pressure (in the location where the exhaust gases are released) is utilized.

In the last case $(\mathrm{C})$, the recirculation of exhaust gases was driven not only by the total-static pressure difference but also by an additional pressure difference generated by the venturi implemented into the mixing pipe (Fig. 5). On the other hand, due to the fact that the recirculating pipe in the case $\mathrm{C}$ has a higher diameter $(6 \mathrm{~mm})$ than in the cases $\mathrm{A}$ $(3 \mathrm{~mm})$ and $\mathrm{B}(4 \mathrm{~mm})$, the axial velocity of the recirculated exhaust gases $(10 \mathrm{~m} / \mathrm{s})$ is smaller than in the others cases $A$ $(22.95 \mathrm{~m} / \mathrm{s})$ and $\mathrm{B}(16.13 \mathrm{~m} / \mathrm{s})$. Each of the three IFGR cases was designed in a way to obtain the greater mass flow of the recirculated exhaust gases.

In the case $\mathrm{A}$, the recirculation velocity is the highest and this is a desired phenomenon because the recirculated part of the exhaust gases permits to cool the IFGR pipe passing across the combustion zone. In the case $\mathrm{B}$, the recirculating velocity in the IFGR pipe is not as important as in the case A, because this pipe is located in the cool part of the combustor; the pipes are located between the liner and the external housing of the combustor. In the last IFGR case (C), as in the case B, the recirculated exhaust gases velocity is not of crucial importance, because the IFGR pipe is connected to the mixing pipe inside of the liner, a location which is out of the major combustion zone.

Summarizing the IFGR system solution cases, one must notice the fact that case $\mathrm{C}$ procures the higher IFGR ratio while having the lowest recirculation velocity in the IFGR pipe. The case A presents the totally inversed parameter compared to the case $\mathrm{C}$. The case $\mathrm{B}$ is an intermediate case in terms of mass flow and velocity of recirculated exhaust gases. The design of the IFGR systems in the cases B and C permits them to have lower recirculating exhaust gases velocity without exposing the IFGR pipe to overheat. Taking into account the mass flow and the design safety (in terms of overheat), the designs presented in the cases B and $\mathrm{C}$ seem to be the most appropriates.

\subsection{Impact of the IFGR system on the pressure drop}

Another parameter taken into account during the analysis of the IFGR concept is the total pressure drop in the combustor. Table 5 presents the total pressure drop in each case, calculated with equation 3 .

$$
\Delta \mathrm{p}^{*}=\frac{\mathrm{p}_{2}^{*}-\mathrm{p}_{3}^{*}}{\mathrm{p}_{2}^{*}} \cdot 100
$$

Table 5. The total pressure drop in the combustor

\begin{tabular}{|l|c|}
\hline Case & $\Delta \mathrm{p}^{*}[\%]$ \\
\hline Reference & 10.00 \\
\hline Case A & 10.12 \\
\hline Case B & 10.49 \\
\hline Case C & 10.78 \\
\hline
\end{tabular}

It was observed that the smallest total pressure drop is ensured in the referential combustor $(10 \%)$. This fact is not surprising, because in the IFGR cases were introduced extra IFGR pipe systems, sources of additional flow resistance. The case A has a total pressure drop equal to $10.12 \%$, in the case $\mathrm{B}$ it is equal to $10.49 \%$ and in the case $\mathrm{C}$ it is equal to $10.78 \%$. Being strict in terms of the values, the most advantageous IFGR case is the case A. Taking into consideration the fact that the total pressure drop rises just around $0.78 \%$ and the fact that the cases $\mathrm{B}$ and $\mathrm{C}$ ensure the higher mass flow of the recirculated exhaust gases, it may be considered that the best cases to be taken into consideration are still the cases B and C.

\subsection{Impact of the IFGR system on the temperature field}

The static temperature homogeneity in the combustor was described in the first part of this section. Differences in the temperature field in the studied cross section were visi- 
ble in each case (Fig. 8). In the referential case, a hot-spot near the outlet of the mixing pipes and near the liner internal perimetrical wall can be observed.

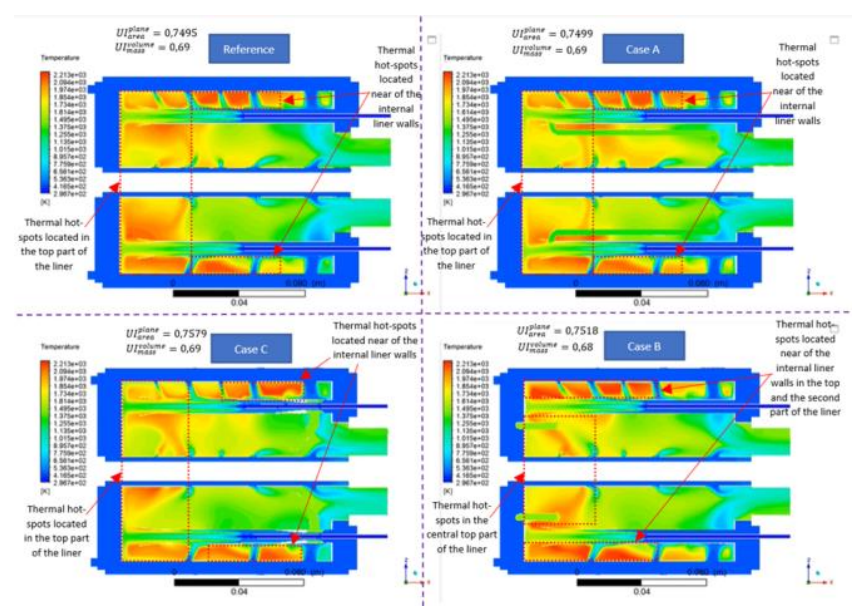

Fig. 8. Static temperature $[\mathrm{K}]$ field comparison

In the case A, the temperature field with a more homogeneous gradient around the mixing pipe outlet can be noticed and the hot-spots are still present near the liner internal perimetrical walls (Fig. 8). This least hot-spot is even larger than in the referential case. Observations prove that the presence of the exhaust gases in the combustion zone affects the combustion process and thus the temperature field.

In case $B$, the recirculation system permits to inject a stream of exhaust gases in the top central part of the liner. This enhances a more homogenous temperature gradient in the vicinity of the mixing pipes outlets, but just in the central part of the liner. In the top internal wall close to the liner an important hot spot can be noticed. The presence of this hot spot is comprehensive in terms of the recirculated part of exhaust gases entering the central location of the liner and not in the perimetrical location of the liner. Near the liner internal perimetrical wall in the second part of the liner, as in the previous case (referential and A), there is a hot-spot. These observations are presented in Fig. 8.

In the last studied case $(\mathrm{C})$, the part of the recirculated exhaust gases is moved into the combustion zone by the mixing pipe, like in the case $\mathrm{A}$, but with the highest mass flow of exhaust gases. This phenomenon affects the combustion zone in the top part of the liner. The temperature gradient is the most homogeneous compared to the others cases. This is the most advantageous effect in terms of the temperature field gradient in the top location of the liner. This effect is less intensive in the second part of the liner. Near the internal perimetrical walls the hot spot is present, as in the others cases, but it is smaller. This description permits to remark that the case $\mathrm{C}$ presents the best particularities in terms of the temperature field gradient. The described case $\mathrm{C}$ is presented on Fig. 8.

Summarizing the above analysis, the case $\mathrm{C}$ has the strongest impact on the temperature field. Cases A and B are less affected by the recirculated exhaust gases. This is linked to the mass flow of the recirculated gases and its injection location. According to the descriptions performed above, the temperature field gradient is more homogeneous in the locations where the recirculated gases are injected.

It was shown that each of the obtained mass flow of the recirculated exhaust gases is sufficient to affect the combustion processes. The fact that the temperature field is more homogeneous isn't necessarily equivalent to the reduction of the peak temperature. It may happen that the average temperature in the combustion zone may rise. Even with a higher temperature peak it may result in more homogeneous combustion (lower temperature gradient).

According to the performed visual analysis, the most homogenous temperature field is in the case $\mathrm{C}$. The temperature field homogeneity increases from the reference case to the case $C$. This visual analysis is supported by the value of the static temperature uniformity index related to the area (equation 4). In the reference case the static temperature uniformity index related to the area is 0.7495 , for the case A it is 0.7499 , for the case B it is 0.7518 and for the case C it is 0.7579 . The static temperature uniformity index is similar in all cases and is around 0.75. This analysis is performed just on one selected plane. While computing the static temperature uniformity index related to the mass (equation 5) in the whole 3-D computational domain, all cases have a value of 0.69 . Exception is the case B, for which the value is 0.68 . This exception is linked to the fact that the IFGR system consists of a set of six pipes located between the liner and the external housing. It indicates that the IFGR system doesn't effectively impact the global static temperature homogeneity in the combustor.

$$
\begin{aligned}
& \mathrm{UI}_{\text {area }}^{\text {plane }}=1-\frac{\sum_{\mathrm{i}=1}^{\mathrm{N}}\left[\left(\left|\mathrm{T}_{\text {face }_{\mathrm{i}}}-\mathrm{T}_{\text {average }}\right|\right) \cdot \mathrm{A}_{\mathrm{i}}\right]}{2 \cdot \mathrm{T}_{\text {average }} \cdot \sum_{\mathrm{i}=1}^{\mathrm{N}}\left[\mathrm{A}_{\mathrm{i}}\right]} \\
& \mathrm{UI}_{\text {mass }}^{\text {volume }}=1-\frac{\sum_{\mathrm{i}=1}^{\mathrm{N}}\left[\left(\left|\mathrm{T}_{\text {cell }_{\mathrm{i}}}-\mathrm{T}_{\text {average }}{ }_{\text {ass }}\right|\right) \cdot\left(\mathrm{V}_{\mathrm{i}} \cdot \rho_{\mathrm{i}}\right)\right]}{2 \cdot \mathrm{T}_{\text {average }} \operatorname{mass}_{\mathrm{i}} \cdot \sum_{\mathrm{i}=1}^{\mathrm{N}}\left[\mathrm{V}_{\mathrm{i}} \cdot \rho_{\mathrm{i}}\right]}
\end{aligned}
$$

The above study dedicated to the static temperature homogeneity permits to remark that the implementation of the IFGR system has a local impact on the combustion processes and temperature homogeneity, but the global effect, inside of the whole combustor, is less visible.

In the second part of this section, the evolution of the maximum static temperature in the combustor will be discussed.

Figure 9 shows that the maximum static temperature in the combustor increases from the reference case to the case C. This phenomenon originates from two facts. The first fact is that the IFGR system impacts the equivalence ratio in the combustion processes. This equivalence ratio modification may provoke the apparition of a combustion zone which is near to the stochiometric conditions. This might result in the increase of the local combustion temperature. The second fact is that the exhaust gases replace a part of the fresh air in the top of the liner. The exhaust gases have higher temperature than the air coming from the compressor, which can increase the combustion peak temperature in the top part of the liner. 


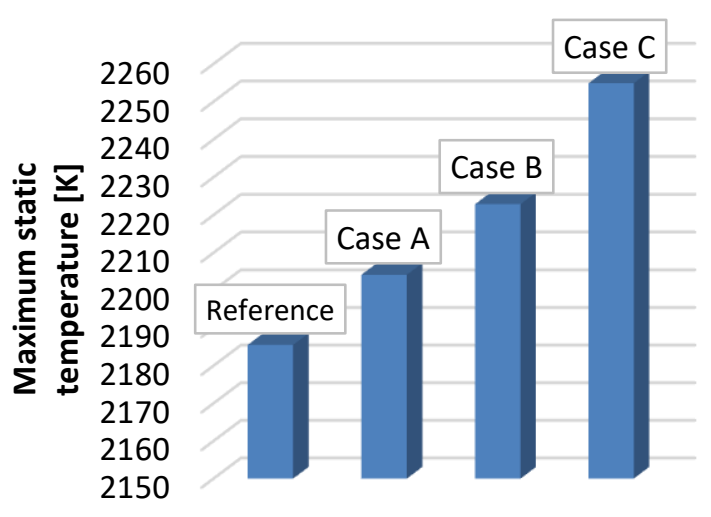

Fig. 9. Maximum static temperature in the combustors

The total exhaust temperature evolution in the combustor was analysed in the third part of this section and presented in Fig. 10. The maximum mass averaged total temperature at the outlet of the combustor is noticed in the case A $(1230 \mathrm{~K})$, and the lowest in the case $\mathrm{C}(1228 \mathrm{~K})$. The difference is just about $2 \mathrm{~K}$, which is a negligible value. It shows that the implementation of the IFGR system doesn't affect the total exhaust temperature.

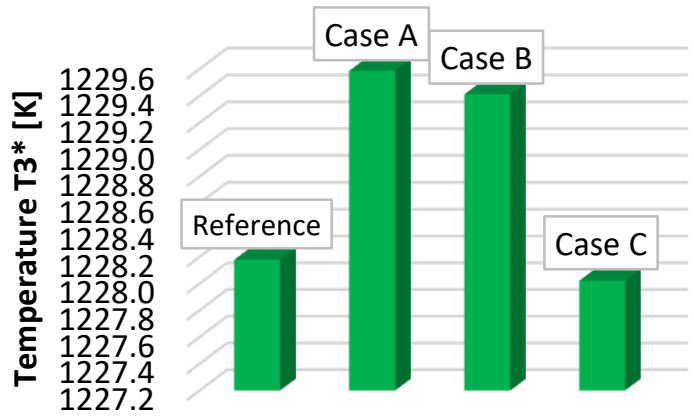

Fig. 10. Total exhaust gases temperature

\subsection{Impact of the IFGR system on the $\mathrm{CO}$ and $\mathrm{NO}_{\mathrm{x}}$ emissions}

The CO dry emissions are presented in Fig. 11. The CO emissions meet a decreasing evolution from the referential to the $\mathrm{C}$ case combustor. For all IFGR cases, the $\mathrm{CO}$ emissions are under the value of $10 \mathrm{ppm}$. The decreasing values of the $\mathrm{CO}$ emissions are corresponding to the increase of the maximum combustion temperature and the recirculated part of the exhaust gases mass flow. This $\mathrm{CO}$ emission reduction may be linked with two facts. The first is that the combustion temperature from the referential case to the $\mathrm{C}$ case increases, and it is the factor that makes this emission decreases. The second fact is that a part of CO present in the exhaust gases is recirculated into the combustion zone, and the $\mathrm{CO}$ of this part of the exhaust gases is reburnt, causing the $\mathrm{CO}$ emission reduction in the IFGR cases.

The $\mathrm{NO}_{\mathrm{x}}$ dry emissions are presented in Fig. 12. In terms of $\mathrm{NO}_{\mathrm{x}}$ emissions, there is an augmentation from the referential to case $\mathrm{C}$ combustor. In the case of the referential combustor the $\mathrm{NO}_{\mathrm{x}}$ emission is around $127 \mathrm{ppm}$, while for the last case $(\mathrm{C})$, the $\mathrm{NO}_{\mathrm{x}}$ emission is around $140 \mathrm{ppm}$. In this kind of power devices, the $\mathrm{NO}_{\mathrm{x}}$ emission is strongly linked to the thermal NO mechanism. As the maximum combustion temperature increases from the referential to the case $\mathrm{C}$ combustor, the $\mathrm{NO}_{\mathrm{x}}$ emission also increases from the referential case to the case $\mathrm{C}$. These results are coherent with the $\mathrm{CO}$ emissions and the maximum combustion temperature evolutions.

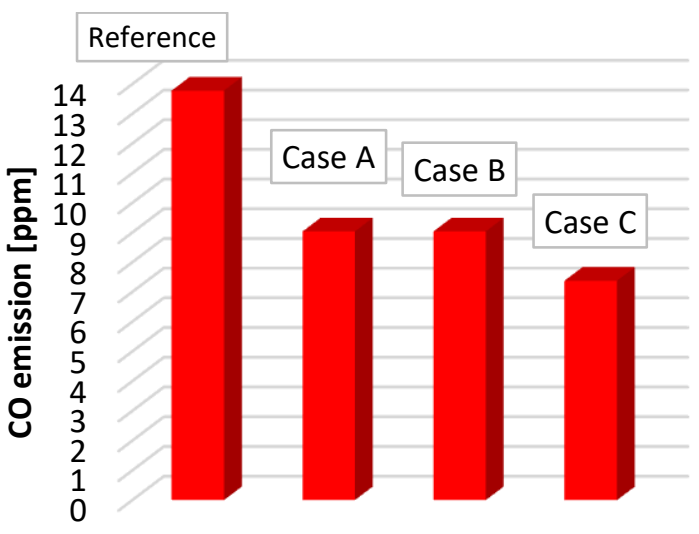

Fig. 11. The $\mathrm{CO}$ emissions

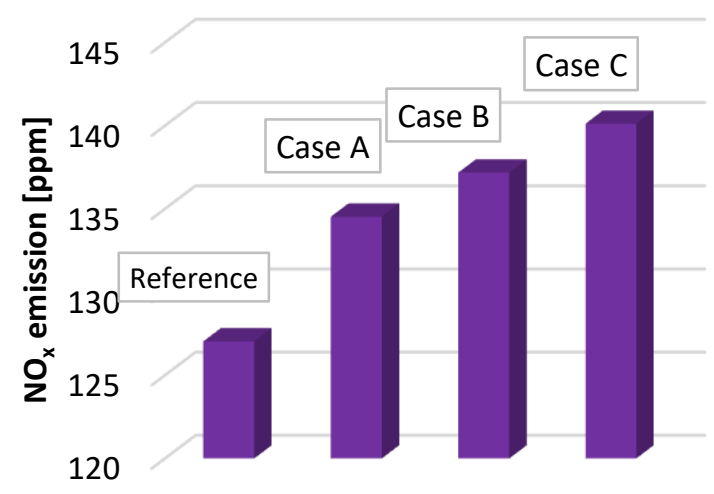

Fig. 12. The $\mathrm{NO}_{\mathrm{x}}$ emissions

To sum up the emissions consideration of the IFGR concept, it must be underlined that the IFGR case $\mathrm{C}$ is the most advantageous in the context of $\mathrm{CO}$ emissions, while being the worst in terms of the $\mathrm{NO}_{\mathrm{x}}$ emissions. In the context of the $\mathrm{NO}_{\mathrm{x}}$ emissions, the referential case is the most advantageous, while being the worst in terms of the $\mathrm{CO}$ production. This may be explained by the augmentation of the maximum combustion temperature (hot-spots) from the case A to the case $\mathrm{C}$. This first study permits to demonstrate that the IFGR concept adopted for the gas microturbine combustors permits to reduce the $\mathrm{CO}$ emissions, while provoking the $\mathrm{NO}_{\mathrm{x}}$ augmentation.

\section{Conclusion}

This study exposes the IFGR concept adapted to the gas microturbine combustor as well as the numerical investigation of the referential and three IFGR combustors. The results were examined and brought several conclusions listed below:

- by applying the adequate pipe system into the referential combustor, it is possible to achieve the recirculation of a part of the exhaust gases, 
- the IFGR combustor case $\mathrm{C}$ permits to obtain the maximum mass flow of the recirculated exhaust gases. In addition to the total-static pressure difference, a Venturi shaped channel was added in the mixing pipe,

- the introduction of the IFGR pipe system into the referential model of the combustor provoked a negligible augmentation of the total pressure drop between the inlet and outlet of the combustor (the increase of the total pressure drop has a maximum value of $0.8 \%$ - case $\mathrm{C}$ ),

- the introduction of the exhaust gases into the combustion permitted to softly homogenize the temperature field on the analysed plane, especially in the case C,

- the introduction of the exhaust gases into the combustion doesn't significantly affect the temperature homogeneity in the whole combustor,

- the maximum combustion temperature increases successively from the referential to the $\mathrm{C}$ case combustor. It is a consequence of modifying the equivalence ratio in the combustion zone of the liner, introducing hot exhaust gases into the fresh air entering inside of the mixing pipe and reburning the $\mathrm{CO}$ present in the exhaust gases,

- the implementation of the IFGR system doesn't impact the exhaust total temperature,

- the application of the IFGR system in the combustor permits to reduce the emission of the $\mathrm{CO}$ species, especially in the case $\mathrm{C}$ combustor. It is the consequence of reburning part of $\mathrm{CO}$ present in the exhaust gases and increasing the maximum combustion temperature,

- the implementation of the IFGR system into the combustor provokes the increase of $\mathrm{NO}_{\mathrm{x}}$ emissions, which is linked with the increase of the maximum combustion temperature (explained above), and the maximum emission is obtained in the case $\mathrm{C}$ while the minimum in the referential case.

The concept of the IFGR applied in the gas microturbine combustor was investigated numerically and it permitted to demonstrate that an autonomous internal flue gas recirculation is possible and that it has a visible effect on the combustion process. Taking into consideration the mass flow efficiency of the recirculated exhaust gases, the cases B and C (especially C) are the most desirable. At the same time, it was shown that the implementation of the IFGR system doesn't strongly affect the total pressure drop and the exhaust total temperature, which is a positive observation. Taking into account the reduction of the $\mathrm{CO}$ emission, the $\mathrm{C}$ case is the most interesting. Taking into consideration the lowest emission of the $\mathrm{NO}_{\mathrm{x}}$ emissions, the referential combustor is better than the IFRG combustor cases. The IFGR system applied to gas microturbines permits to reduce the $\mathrm{CO}$ emissions. The study permitted also to demonstrate that the IFGR system provokes an increase of the $\mathrm{NO}_{\mathrm{x}}$ emissions. Further investigations will be performed in order to analyse the impact of this IFGR concept in the context of emissions.

\section{Nomenclature}

A

c $\quad \begin{array}{ll}\text { surface }\left[\mathrm{m}^{2}\right] \\ \text { velocity }[\mathrm{m} / \mathrm{s}]\end{array}$

$\mathrm{c}_{\mathrm{s}} \quad$ fuel mass flow $[\mathrm{kg} / \mathrm{s}]$

$\mathrm{CO} \quad$ carbon monoxide

IFGR Internal Flue Gas Recirculation

$\dot{\mathrm{m}} \quad$ air mass flow $[\mathrm{kg} / \mathrm{s}]$

$\mathrm{NO}_{\mathrm{x}} \quad$ nitrogen oxides

$\mathrm{p} \quad$ pressure [Pa]

$\mathrm{T} \quad$ temperature $[\mathrm{K}]$

$\mathrm{T}_{\text {average }} \quad$ average static temperature in the analysed cross-section plane [K]

$\mathrm{T}_{\text {average }}$ mass average static temperature in the analysed computational domain $[\mathrm{K}]$
$\mathrm{T}_{\text {cell }} \mathrm{i}$

$\mathrm{T}_{\text {face }_{\mathrm{i}}}$

$\mathrm{UI}_{\text {area }}^{\text {plane }}$

UI mass

$\mathrm{V}_{\mathrm{i}}$

$\rho_{\mathrm{i}}$

$1,2,3,4$

*index static temperature in the i cell defining the computational domain $[\mathrm{K}]$

static temperature on the facet $\mathrm{i}$ defining the analysed surface [K]

plane area weighted static temperature uniformity index [-]

volume mass weighted static temperature uniformity index [-]

volume of the cell $\mathrm{i}$ defining the computational domain $\left[\mathrm{m}^{3}\right]$

density of the cell $\mathrm{i}$ defining the computational domain $\left[\mathrm{kg} / \mathrm{m}^{3}\right]$

gas microturbine cross section designation total value of a parameter

\section{Bibliography}

[1] LAV, C., KAUL, C., SINGH, R. et al. (2013). Potential of micro turbines for small scale power generation. International Journal of Advanced Information Science and Technology. 2013, 2(5), 35-39.

https://doi.org/10.15693/ijaist/2013.v2i5.77-81

[2] KWON, M., NGUYEN, B.H., KIM, S. et al. Numerical investigation of buoyancy and thermal radiation effects on a mid-/large-sized low $\mathrm{NO}_{\mathrm{x}}$ combustion system with flue-gas internal recirculation. Advances in Mechanical Engineering. 2018, 10(4), 1-17.

https://doi.org/10.1177/1687814018769139

[3] GIERAS, M., STAŃKOWSKI, T. Computational study of an aerodynamic flow through a micro turbine engine combustor. Journal of Power Technologies. 2012, 92(2), 68-79.

[4] SUCHOCKI, T., LAMPART, P., KLONOWICZ, P. Numerical investigation of a GTM 140 turbojet engine. Open Engineering, 2015, 5, 478-484. https://doi.org/10.1515/eng-2015-0053

[5] DIAS, F.L.G., NASCIMENTO, M.A.R., RODRIGUES, L.O. Reference area investigation in a gas turbine combustion chamber using CFD. Journal of Mechanical Engineering and Automation. 2014, 4(2), 73-82. https://doi.org/10.5923/j.jmea.20140402.04 
[6] VIlaG, V., VIlaG, J., CARLANESCU, R. et al. CFD application for gas turbine combustion simulations. In: JI,G., ZHU, J. (Ed.). Computational fluid dynamics simulations. IntechOpen. 2019. https://doi.org/10.5772/intechopen.89759

[7] GONZALEZ, C., WONG, K.C., ARMFIELD, S. Computational study of a micro turbine engine combustor using Large Eddy Simulation and Reynolds Averaged turbulence models. ANZIAM Journal. 2007, 49, 407-422. https://doi.org/10.21914/anziamj.v49i0.338

[8] ANSYS, Inc. Retrieved from https://www.ansys.com/

[9] SOSNOWSKI, M., KRZYWANSKI, J., GNATOWSKA, R. Polyhedral meshing as an innovative approach to computational domain discretization of a cyclone in a fluidized bed CLC unit. E3S Web of Conferences, 2017, 14(01027). https://doi.org/10.1051/e3sconf/20171401027

[10] ZAHID, Q., CHAN, A. A study of the effect of element types on flow and turbulence characteristics around an isolated high-rise building. Eleventh International Conference on CFD in the Minerals and Process Industries, CSIRO. Melbourne 2015.

[11] MATYUSHENKO, A., STABNIKOV, A., GARBARUK, A. Criteria of computational grid generation for turbulence models taking into account laminar-turbulent transition. Journal of Physics: Conference Series, 2019, 1400(7). https://doi.org/10.1088/1742-6596/1400/7/077047

[12] ANSYS, Inc. Ansys Fluent Theory Guide - Release 15.0. 2013.

Jean-Marc Fąfara, MEng. - Faculty of Mechanical and Power Engineering, Wroclaw University of Science and Technology.

e-mail: jean-marc.fafara@pwr.edu.pl
[13] SUCHOCKI, T., LAMPART, P., SURWIŁO, J. Designation of operating characteristics for micro-jet engine and CFD validation. Mechanik. 2015, 7, 813-820. https://doi.org/10.17814/mechanik.2015.7.301

[14] GIERAS, M. Miniaturowe silniki turboodrzutowe (Microturbojet engine). Publishing House of the Warsaw University of Technology, Warsaw 2016.

[15] SMITH, T., SHEN, Z., FRIEDMAN, J. Evaluation of coefficients for the weighted sum of gray gases model. Journal of Heat Transfer. 1982, 104(4), 602-608. https://doi.org/10.1115/1.3245174

[16] FUCHS, F., MEIDINGER, V., NEUBURGER, N. et al. Challenges in designing very small jet engines fuel distribution and atomization. International Symposium on Transport Phenomena and Dynamics of Rotating Machinery, Honolulu 2016.

[17] PETERS, N. Turbulent Combustion. Cambridge University Press. Cambridge 2000.

[18] SMITH, G.P., GOLDEN, D.M., FRENKLACH, M. et al. Grimech 3.0. Retrieved from http://www.me.berkeley.edu/gri_mech/

[19] LAUNDER, B.E., SPALDING, D.B. The numerical computation of turbulent flows. Computer Methods in Applied Mechanics and Engineering. 1974, 3(2), 269-289. https://doi.org/10.1016/0045-7825(74)90029-2

[20] ANSYS, Inc. Ansys Fluent Tutorial Guide - Release 18.0. 2017.

Norbert Modliński, DSc., DEng. - Faculty of Mechanical and Power Engineering, Wroclaw University of Science and Technology.

e-mail: norbert.modlinski@pwr.edu.pl 